\title{
Interreligious Learning as Monotheist Imperative
}

\author{
Reuven Firestone
}

\begin{abstract}
Because seminaries are designed to further the goals of the religious communities that fund and support them, interreligious learning may not be generally accepted as fulfilling their institutional needs. This perspective derives from the history of interreligious polemic and competition between and within monotheist traditions, based on the assumption that God represents a single Truth that cannot be compromised, and that our expression of religion represents that Truth. This essay interrogates these assumptions and argues that true understanding must transcend the limits of religious institution, and offers an instructive way to understand the distinctiveness of one's particular spiritual tradition in relation to other attempts to understand the Infinite.
\end{abstract}

I have been teaching for decades simultaneously in seminary and university settings, and I have had to be cognizant of the different approaches to the teaching of religion therein. It is important to differentiate between seminary and university settings in higher education, and equally important to relate to the two as "ideal-types" (idealtypus) in the Weberian sense, since not all universities are equally open in their quest for knowledge, and not all seminaries are equally constrained by religious creed in their pursuit of understanding. In this essay, I do not discuss the university setting, because, at least in theory, it is open to a highly analytic examination of religion that neither privileges nor disparages any individual religion, or the notion or practice of religion in general. In real life, of course, there is certainly deviation from this norm, but the norm nevertheless stands as the standard educational philosophy for the study of religion in the academy.

This has not been the case with the seminary environment, for understandable reasons. Seminaries are training institutions for the development of thought and character among religious devotees of particular faith communities and, more recently, of clusters of similarly-minded faith communities. 
Seminary training is designed, ultimately, to further the goals of the religious communities that fund and otherwise support them.

Institutional goals are the absolute bottom-line issue in such endeavors. Seminaries are constrained by the institutional goals and values of the religious communities that pay for them. This is a natural phenomenon, of course, since like all other institutions, religions function in one way or another as "living organisms" that do everything in their power to remain healthy and live in perpetuity. ${ }^{1}$ Seminaries are key tools for ensuring the strength, continuity, and durability of religious communities.

The question that lies behind interreligious learning in the seminary setting is "Does interreligious learning fulfill the mandated institutional goals of the religious community represented by the seminary?" There are several ways to answer this question. The traditional response, which does not typify the predisposition of those participating in this project, is that interreligious learning does not fulfill the spiritual mandate of a religious community. This position is time-honored, not unreasonable, and must be considered carefully for obvious religious and intellectual reasons. It must be addressed by those engaged in projects such as ours, at the very least in order to articulate a sensible response to its claims.

The negative position represents the normative historical perspective of communities that have funded seminaries or their equivalent since the rise of the scriptural monotheistic traditions. After all, according to the basic historical narrative shared by scriptural monotheisms since their emergence some three millennia ago, God revealed the divine imperative in a clear and authoritative communication that was carefully recorded into what has come to be known as scripture. ${ }^{2}$ Those who know scripture possess the truth revealed within it. ${ }^{3}$ There can be nothing remotely beneficial from learning anything from those who deny that truth through disagreement (heresy) or misunderstanding (deviant heterodoxy). ${ }^{4}$ In fact, interaction and even association with

1 I do not refer here to evolutionary theories of cognition and adaptation in religious thought and behavior; cf. Pascal Boyer and Brian Bergstrom, "Evolutionary Perspectives on religion," Annual Review of Anthropology 37 (2008): 111-130; Scott Atran and Ara Norenzayan, "Why Minds Create Gods: Devotion, Deception, Death and Arational Decision Making," Behavioral and Brain Sciences 27, no. 2 (2004): 754-70. Rather, I am referring to simple mechanisms for religious institutional survival; see Rodney Stark and William Sims Bainbridge, The Future of Religion: Secularization, Revival and Cult Formation (Berkeley and Los Angeles: University of California Press, 1985).

2 Deut. 30:11-14; Ps. 19:7-9; 119:105, 130; 2 Cor. 4:6; 2 Tim. 3:14-17; Qur'an 12:2; 44:58, etc.

3 Ps. 86:11, 119:16o; Dan. 10:21; John 17:17, 14:6; Eph.1:13-14; Jas. 1:18; Qur'an 2:144-47, 2:176; 5:48.

4 John B. Henderson, The Construction of Orthodoxy and Heresy (Albany, NY: State University of New York Press, 1998). 
those espousing different religious ideas or creeds is dangerous and may lead to punishment in this world and the next.

\section{Monotheism and its Limitations}

This binary division between the revealed truth and all else, which has characterized the conventional religious worldview shared by scriptural monotheisms, represents a serious barrier to interreligious learning and dialogue. The binary perspective derives at least to some extent from the history of religious genesis, or at least the history of the emergence of monotheisms in the ancient Near East. Prior to the emergence of monotheisms, there was seemingly infinite variation of a single social-spiritual system comprised of what we call today religion, culture, ethnicity, kinship, and politics. ${ }^{5}$ Gods governed the natural world, and gods were also attached to communities. Some gods existed in a covenantal relationship with tribal communities. ${ }^{6}$ Others were urban gods who protected and were sustained by their communities of worshipers in town or city environments. ${ }^{7}$ These were in a symbiotic relationship with their human worshipers, who fed them through offerings and received beneficence from them in return. People worshiped other powers as well, ones associated with fertility, the weather, death and disease, bodies of water, stars and the heavens, and other aspects of nature. ${ }^{8}$ The names of these gods varied by culture and language but their roles were identical. ${ }^{9}$ Together, they represented a kind of universal religion in infinite variation. Various gods were associated with various powers and attributes. They gave various directives and expected

5 The following observation reflects a modern, academic historian's perspective. It differs from the religious narratives of Judaism, Christianity and Islam, each of which has its own perspective on the origins of monotheism.

6 The most obvious examples come from the Hebrew Bible, which archaeology and paleography confirm is a fairly basic representation of the ancient Near East. Tribal gods include, for example, Chemosh of the Moabites (Num. 21:29), Milkom of the Ammonites (1 Kgs. 11:6), Dagon of the Philistines (1 Sam. 5), and even El-Berit, "God of Covenant," who was the god of Shechem (see note 7 below). For lists of tribal and other such deities known to the biblical world, see 2 Kgs. 17:29-31, 23:4-11.

7 Ashtoret in Tyre, for example (2 Kgs. 23:13), or El-Berit or Ba'al Berit in the city of Shechem (Jdg. 9:4, 46).

8 Frank Moore Cross, Canaanite Myth and Hebrew Epic (Cambridge, MA: Harvard University Press, 1975); Mark S. Smith, The Early History of God: Yahweh and the Other Deities in Ancient Israel (Dearborn, MI: Eerdmans, 2002); Glenn Holland, Gods in the Desert: Religions of the Ancient Near East (New York: Rowman and Littlefield, 2010).

9 Jan Assmann, Of God and Gods: Egypt, Israel, and the Rise of Monotheism (Madison, WI: University of Wisconsin, 2008), 53-58. 
various acts from their worshipers. These ancient Near Eastern religions and their gods have not survived, though many aspects of their religious thought and practice survive in part among the monotheistic religions that are their heirs. ${ }^{10}$

With the emergence of monotheism - the result of a very long process of transition ${ }^{11}$ - the notion of a single creator god responsible for the entire world gave rise to a very different worldview. Many gods could communicate many different, even conflicting, messages, because each deity controlled only a portion of the world and nature. A single God responsible for the entire world is not only much more powerful, it represents a unity and consistency unimaginable in a multi-theistic world. The very unity of God, along with the assumption of divine omniscience and omnipotence, suggests a kind of uniformity and absolute accuracy in any communication that derives from God.

With divine unity comes a unified message. ${ }^{12}$ This eminently logical conclusion demands a unified human response to God's expectations and demands. ${ }^{13}$ However, if there is any one common human trait that crosses all cultures and communities, it is that people do not respond in a unified manner to any imperative, even a divine imperative.

\section{3}

\section{Internal Strife and the Formation of New Religion}

Monotheisms have always been plagued with sectarianism wrought of disagreement. Humans differ. People are individual, sentient beings that see and interpret the world in an autonomous manner and in remarkably diverse ways, and who frequently disagree. This often results in the formation of sub-units within any group. When internal disagreements within communities become great enough, they lead to further factionalization, and when the rift between factions becomes great enough, they subdivide into competing camps, which

10 Ziony Zevit, The Religions of Ancient Israel: A Synthesis of Parallactic Approaches (London: Continuum, 2001); Mark S. Smith, The Origins of Biblical Monotheism (Oxford: Oxford University Press, 2001); Cross, Canaanite Myth and Hebrew Epic.

11 Nili Fox, "Concepts of God in Israel and the Question of Monotheism," in Gary M. Berkman and Theodore J. Lewis eds., Text, Artifact, and Image: Revealing Ancient Israelite Religion (Atlanta, GA: SBL Brown Judaic Studies, 2006), 326-45.

12 Reuven Firestone, "A Problem with Monotheism: Judaism, Christianity, and Islam in Dialogue and Dissent," in Bradford Hinze, ed., Heirs of Abraham: The Future of Muslim, Jewish, and Christian Relations (New York: Orbis, 2005), 20-54; Martin Jaffee, "One God, One Revelation, One People: On the Symbolic Structure of Elective Monotheism," Journal of the American Academy of Religion 69, no. 4 (2001): 753-75.

13 Jan Assmann, Of God and Gods, especially chapter 6 (106-26). 
sometimes requires a complete separation and the formation of discrete communities. This process can result in the emergence of new religions.

Among scriptural monotheisms, new religion requires new scripture. ${ }^{14}$ Otherwise, the emergent (or divergent) community retains a sectarian and thus secondary status under the authority of power structures based on existent scripture. Most sub-groups within religious communities remain within the larger community as sectarian movements or schisms. ${ }^{15}$ The authority for sectarian movements rests on the power of interpretive argument in a world in which the ruling religious factions control the discourse. This phenomenology of sectarian formation, which always occurs in environments of contention, raises the polemical rhetoric of both established religions and sectarian movements. Each argues against the other in order to promote its own position, and these arguments become integrated into the worldview or personality of the religion or movement that espouses them. An antagonistic perspective is encouraged, not only toward the particular group it is arguing against, but toward all foreign or different religious expression,. Sectarian groups may eventually become reabsorbed into the larger community for a variety of reasons, or their differences may increase until they are excommunicated or even destroyed by the larger community.

In some cases, a sectarian group finds a new source of divine authority, usually understood as a new divine communication that surpasses or supersedes the previous. In this situation, the authority of the group then rests directly with God through the new communication, which it claims supplants the authority of previous scripture.

The claim of a new revelation of the divine imperative challenges established religion and threatens its authority. What emerges is a kind of existential competition between communities that cannot be resolved because both claim ultimate authority in a different divine disclosure, each version of which is understood to represent the absolute will of an omnipotent and omniscient God. This sets up an eternal conflict that is, ultimately, unresolvable. Each community claims that its scripture transcends any authority vested in the

14 This statement needs to be qualified somewhat, since in certain taxonomies Catholic Christianity, Evangelical Christianity, and Russian Orthodox Christianity may be considered to be entirely different religions. For the purposes of this analysis, I consider them all representations of Christianity. A current idiom in Religious Studies is "Christianities." The cluster of communities listed above are all Christianities, as opposed to Judaism(s) and Islam(s), each cluster of which relies on a different scripture.

15 Roger Finke and Christopher Scheitle, "Understanding Schisms: Theoretical Explanation for their Origins," in James R. Lewis and Sarah M. Lewis, eds., Sacred Schisms: How Religions Divide (Cambridge: Cambridge University Press, 2009), 11-33. 
other. This can best be described as a form of zero-sum competition. There is no compromise with the divine imperative. Given the natural history of relationship between monotheist communities, should we then be surprised that honest and curious interreligious learning among them was typically forbidden? On the contrary, the purpose of learning about the religious other traditionally has been to attack and disparage competing claims for truth and wisdom. As Bishop Krister Stendahl famously indicated by his three rules of religious understanding, it is common when engaging in comparative religion to compare the "best" of one's own religion with the "worst" of the other. ${ }^{16}$

In situations of religious conflict (the usual state of affairs between monotheist religious communities) religious validity rests on the authority and success of argument. Sectarian formation, which always occurs in environments of contention, increases the level of polemical rhetoric within both the established religion and the sectarian movement. This has had a profound impact on interreligious learning. On the one hand, the development of polemical literatures in the scriptural monotheisms has promoted an interest in knowing the views of the religious adversary, but its intention is to refute the claims and deny the validity of the religious other. In the process, polemical works often fail to understand the actual perspectives and beliefs of the religious other, and in many cases, they misrepresent and distort them.

\section{Modernity, Science, and a Shrinking World}

In the pre-modern world intolerance was a virtue. Those with reliability and integrity, demonstrated by unwavering adherence to their beliefs, were people whom we would consider today to be intolerant. Such people had the wisdom, discernment, and métier to actively refute the untruths, lies, and undercutting of those who held contrary positions and were, by definition, divergent and therefore hostile to the divine will and the truth of God. The root of this logic, according to Jan Assmann, is an inherent totalistic perspective that lies at the very core of monotheism. Assmann has argued that the crucial element of monotheism "is not the distinction between One God and many gods, but the distinction between truth and falsehood in religion, between the true god and

16 Barbara Brown Taylor, "My Holy Envy of Other Faith Traditions," Christian Century, March 7, 2019, accessed October 11, 2019, https://www.christiancentury.org/article/critical-essay/ my-holy-envy-other-faith-traditions. 
false gods, true doctrine and false doctrine, knowledge and ignorance, belief and unbelief."17

If we know the truth, why should we sully it or allow ourselves to be tempted away from it by the untruths of those who claim truth in falsehood? This perspective precludes the possibility of learning about others' religious ideas and practices, since any claims for a different view of truth are by definition false and, therefore, evil.

The sense of confidence described above largely fell away as the world entered modernity. In the modern era, a gradual change in thinking resulted, ultimately, in the relativization of the construction or perception of truththough not the relativization of truth itself. The modern pursuit of science required constant redefinition and refinement of the laws of nature. Science did not deny the existence of any absolute truth, but the scientific process taught that our understanding of truth is limited and could always be improved through better method and perspective. This view reached a kind of philosophical apogee with the realization that certain absolute, unchanging laws of physics could not be accurately and equally experienced by observers who encountered them from different perspectives. ${ }^{18}$ While a single "Truth," therefore, could indeed exist, we have come to accept the fact that our experience of it, at least in the world of science, is inherently limited.

Modern science profoundly influenced all social and humanistic fields, from social philosophy to theology. How do we know what we know, and how can we know that we even know it? The discipline of epistemology, an old premonotheist, a-religious discipline, was revived and revised in the modern world. Under the influence of both physics and social science, it reconceptualized our consciousness of the notion of reality and the truth that it represents to the observer. "Concrete reality is therefore entirely subjective and individual, and so-called objective reality disappears, for it is simply an abstract concept that we all share."19

Not only did science modify our outlook, so too did the revolution of travel. While the shrinking of the world initially allowed for the forced imposition of the conquerors' worldviews onto the conquered, it soon became evident to the discerning that what was unwittingly regarded as "primitive" or subaltern

17 Jan Assmann, The Price of Monotheism (Redwood City, CA: Stanford University Press, 2010), 2.

18 Max Born, Einstein's Theory of Relativity (New York: Dover, 1965).

19 This citation comes from Kitaro Nishida's inquiry into experience and reality in An Inquiry into the Good, trans. Masao Abe and Christopher Ives (New Haven, CT: Yale University Press, 1990), 74. This work was originally published in Japanese, Zen no kenkyū (Tokyo: Iwanami Shoten, 1921), 74. 
could in fact be enlightened and extraordinary. The "discovery" of foreign wisdom that seemed to align with the wisdom of the West opened up the possibility of observing commonalities within (or despite) difference. The discovery of certain shared features or attributes, however, did not immediately open up the world to an appreciation of wisdom in general. One reaction to the realization of commonalities prompted the impulse to prove the superiority of one's own wisdom, culture, and tradition over that of the other. Yet another response was simply to learn without feeling the need to judge and dominate. The latter impulse opened up the possibility of engagement with the religious other in a genuinely dialogical manner.

This process evolved in three stages. The initial comparative impulse was self-aggrandizing, undertaken to hone one's sense of truth and worth by contrasting it with the falsity and unworthiness of the other. Then came the discovery of commonalities and the impulse to reflect on how religions share common or similar traits and aspirations. Finally, some came to realize that deeper wisdom comes neither from value judgments nor from affirmation based on likeness, but rather from the stimulation deriving from reflection on the nuanced subtleties of difference and the illumination that springs from their value-free contemplation. In the last few decades a number of important collections have been published that take this kind of embracing comparative approach. $^{20}$

\section{Truth and the Religious Imperative}

Religions are complex organisms. Like living beings, they are made up of impulses and drives and they are hardly consistent. One of the traditional goals of systematic theology among the scriptural monotheisms has been to resolve what appears inconsistent in religion, because inconsistency conflicts with the primary authority for all things religious: an omniscient and omnipotent God. ${ }^{21}$

Religions are also complex because as much as they represent God, they also represent those who adhere to God. God reveals; humans respond—-this is

20 John Hick and Edmund Miltzer, eds., Three Faiths One God: A Jewish, Christian, Muslim Encounter (Albany, NY: State University of New York Press, 1989); James Heft, Reuven Firestone, and Omid Safi, eds., Learned Ignorance: Intellectual Humility among Jews, Christians and Muslims (New York: Oxford, 2011); Catherine Cornille, The Wiley-Blackwell Companion to Inter-Religious Dialogue (West Sussex, UK: Wiley-Blackwell, 2013).

21 This is a very large field. For an introduction to the issues, see Wayne Grudem, Systematic Theology: An Introduction to Biblical Doctrine (Leicester, UK: Inter-Varsity, 1994). 
a formula that produces religion. Humans cannot help but process the world around them as independent and autonomous beings, so the religions they experience also contain a complex array of arcs and paths through which they respond by way of thought and practice to the divine imperative.

Religions contain a range of thinking about almost everything. They are both inward-looking and outward-looking. They reflect a powerful need for hierarchy, yet they are often extremely anti-hierarchical. They react to threat and conflict with an assortment of responses, from extreme violence to radical nonviolence. They lean sometimes toward universalism and sometimes toward particularism. These vectors or trajectories of thought and practice are the very essence of religion.

The theological differences between the scriptural monotheisms are best understood through the language of relative measure. Even classic, defining differences, such as the nature of God's essence via Trinitarian theology in Christianity and anti-Trinitarian theologies in Judaism and Islam, are not absolute. Jewish and Islamic mysticism, for example, include schools that observe a division in the Godhead that finds parallels with Trinitarian notions, while some Christian communities reject an essential Trinitarian division altogether. $^{22}$

It was right to conclude, as our monotheist ancestors did, that in one creator God there exists an essential unity in the created universe, which continues to move it to this day. It was also correct to conclude that from this essential unity there is most likely an actual, single Truth. It is a mistake, however, to think that we can "own" that truth, that anyone can truly know it. As we move through history and learn new and ever-expanding quantities of information about both cosmos and microcosmos, it is the quintessence of temerity to think that we could possibly be confident that we understand "God's truth."

So, what do we do about it? We do what seekers have always done. We learn, both from within and outside of our particular religious tradition..$^{23}$ Learning

22 Harold Gutteridge, The Esoteric Codex: Nontrinitarianism (NP: Lulu.com, 2012); Yehuda Liebes, "Christian Influences on the Zohar," in Liebes, Studies in the Zohar (Albany, NY: State University of New York Press, 1993), 139-56. Jonatan Benarroch most recently treats Trinitarian ideas as they appear in the Zohar; "Sava and Yanuka": God, the Son and the Messiah in Zoharic Narratives - Poetic and Mythopoetic Aspects (Hebrew, Jerusalem: Magnes Press, forthcoming); Ian Netton, Islam, Christianity and the Mystic Journey (Edinburgh: Edinburgh University Press, 2011), 100, 114-17.

23 There are myriad ways we can engage in interreligious learning, from discussing theology to studying different scriptures, observing rituals, and even engaging with people of various religious faiths in unrelated projects of common interest, such as working at food pantries. While it is not the topic of this particular essay, the art and science of interreligious engagement is an important expertise. 
is always a bit risky because it changes us. Most often, however, the changes that derive from learning deepen our sense of who we are and our sense of being grounded in a very complex world. In my own engagement with believers of other faith traditions through discussion, scriptural reading, and observing prayer, I have come not only to deepen my personal relationship with the Ultimate but also to strengthen my connection with the particularity of my own religious tradition. Additional angles of perspective offer additional possibilities of understanding.

The seminary is the place where we learn the unique and remarkable wisdom that our particular religious communities have derived from their efforts to understand the meaning of the Ultimate, and where we learn how our communities have responded to what we understand as the divine imperative. Our individual traditions contain great wisdom and extraordinary insights about these, but they do not contain all Truth because that is simply impossible. Nor are our individual seminary approaches or methodologies the only or even the most complete way to learn. The best we can do is to unpack a slice of Truth from the efforts of our religious predecessors and teachers. They-and weare limited by the particularity of our own traditions. If we are serious about learning we need to open ourselves to Truth as understood by followers of other faith traditions.

I would argue that this is the new religious imperative. Even our broadest and deepest particular experiences are limited. We need to encourage our seminarians to experience the interpretive processes as well as conclusions of other faith traditions. One of the most effective and exciting ways to do this is by engaging with seminarians of other faith traditions. While it may seem natural or intuitive to engage with members of other scriptural monotheisms, it need not and should not be limited to "monotheists." The Ultimate speaks through the longing of all creation.

Seminary Learning

We expand and deepen our own religious understanding by learning with our religious co-travelers from other faith traditions. The new imperative is to learn wisdom not merely from our own tradition but also from others that have posed many of the questions we ask, but from different angles. From these different perspectives followers of other faith traditions derive responses that are unavailable to us because of the confines of our own viewpoints, and they sometimes pose entirely new questions that we could not possibly have thought of. I am not arguing that all perspectives are equal in value, but different 
perceptions deepen our knowledge of what is without and what is within. We know from modern science that even established truths are experienced differently by observers who come to them from different viewpoints. Learning more of the variety of human spiritual experience and thought increases the likelihood of deeper and fuller understanding.

Given the expansiveness of our own religious histories, theologies, and literatures, it might seem that interreligious learning would reduce the amount and quality of wisdom that one could absorb from one's own religious tradition. I do not think interreligious learning requires a great amount of curricular space. One or two well-planned courses may be adequate if supplemented with two additions: experiential engagement with seminarians and religious leaders of other faith traditions outside the classroom framework, and a consistent message that religious and interreligious learning must continue after seminary training.

One of the important lessons conveyed to rabbinical students of all denominations in my own Jewish community is that ordination marks the culmination of only an early stage in the journey of learning. Learning about Jewish text and tradition becomes part of a rabbi's culture, and daily learning is expected to be a part of any rabbinic job description. Inculcated learning is built into the curriculum of Jewish seminary education. It should also include the expectation that seminary graduates engage with their religious counterparts of other faith communities, and that such engagement can (and should) trickle down into the communities they serve.

God reveals and humans respond. As noted above, the inevitably autonomous human response to the Ultimate is one of the miracles of creation. We think and we feel, and we are uniquely cognizant of sensing the world around us. If there is anything that captures the biblical references to humans having been created in the likeness of God, ${ }^{24}$ it is this. We have somehow been given the tools - the gifts - of cognition, sentience, and self-awareness. The best way to take advantage of this extraordinary, God-given aptitude is to learn from one another.

24 Gen.1:27, 2:26, 9:6. This position is not found in the Qur'an and is controversial among some Muslims. However, the canonical Hadith includes traditions on the authority of Muhammad that God created Adam in his own likeness (halaqa Allāhu Ādam 'alā șüratihi). The source is Șahịh Bukhārī, given on the authority of Abū Hurayra citing the Prophet (Bukhārī, Șaḥịh, 79, "Al-Isti'dhān," 1, Beirut: Dār al-Kutub al-'Ilmiyya, 1420/1999, 4:142). See also Aḥmad b. Ḥanbal, Musnad, "Musnad Abī Hurayra," 8191, Beirut: Dār alKutub al-'Ilmiyya, 1413/1993, 2:421. 


\section{Bibliography}

Assmann, Jan. Of God and Gods: Egypt, Israel, and the Rise of Monotheism. Madison, WI: University of Wisconsin Press, 2008.

Assmann, Jan. The Price of Monotheism. Redwood City, CA: Stanford University Press, 2010.

Atran, Scott, and Ara Norenzayan. "Why Minds Create Gods: Devotion, Deception, Death and Arational Decision Making." Behavioral and Brain Sciences 27, no. 6 (2004): 754-70.

Benarroch, Jonathan. "Sava and Yanuka": God, the Son and the Messiah in Zoharic Narratives-Poetic and Mythopoetic Aspects. Hebrew, Jerusalem: Magnes Press, 2019.

Born, Max. Einstein's Theory of Relativity. Reprint. New York: Dover, 1924, 1965.

Boyer, Pascal, and Brian Bergstrom. "Evolutionary Perspectives on Religion." Annual Review of Anthropology 37 (2008): 111-30.

Bukhārī, Muḥammad Abū Abdallah. Șaḥ̄ḥ. Beirut: Dār al-Kutub al-'Ilmiyya, 1420/1999. Cornille, Catherine. The Wiley-Blackwell Companion to Inter-Religious Dialogue. West Sussex, UK: Wiley-Blackwell, 2013.

Cross, Frank Moore. Canaanite Myth and Hebrew Epic. Cambridge, MA: Harvard, 1975. Finke, Roger, and Christopher Scheitle. "Understanding Schisms: Theoretical Explanation for their Origins." In James R. Lewis and Sarah M. Lewis, eds., Sacred Schisms: How Religions Divide, 11-33. Cambridge: Cambridge University Press, 2009.

Firestone, Reuven. "A Problem with Monotheism: Judaism, Christianity, and Islam in Dialogue and Dissent." In Bradford Hinze, ed., Heirs of Abraham: The Future of Muslim, Jewish, and Christian Relations, 20-54. New York: Orbis, 2005.

Fox, Nili. "Concepts of God in Israel and the Question of Monotheism." In Gary M. Berkman and Theodore J. Lewis, eds., Text, Artifact, and Image: Revealing Ancient Israelite Religion, 326-45. Atlanta, GA: SBL Brown Judaic Studies, 2006.

Grudem, Wayne. Systematic Theology: An Introduction to Biblical Doctrine. Leicester, UK: Inter-Varsity, 1994.

Gutteridge, Harold. The Esoteric Codex: Nontrinitarianism. NP: Lulu.com, 2012.

Heft, James, Reuven Firestone, and Omid Safi, eds. Learned Ignorance: Intellectual Humility among Jews, Christians and Muslims. New York: Oxford, 2011.

Henderson, John B. The Construction of Orthodoxy and Heresy. Albany, NY: State University of New York Press, 1998.

Hick, John, and Edmund Miltzer, eds. Three Faiths One God: AJewish, Christian, Muslim Encounter. Albany, NY: State University of New York Press, 1989.

Holland, Glenn. Gods in the Desert: Religions of the Ancient Near East. New York: Rowman and Littlefield, 2010.

Ibn Ḥanbal, Aḥmad. Musnad. Beirut: Dār al-Kutub al-'Ilmiyya, 1413/1993. 
Jaffee, Martin. "One God, One Revelation, One People: On the Symbolic Structure of Elective Monotheism." Journal of the American Academy of Religion 69, no. 4 (2001): 753-75.

Liebes, Yehuda. "Christian Influences on the Zohar." In Yehuda Liebes, Studies in the Zohar, 139-56. Albany, NY: State University of New York Press, 1993.

Netton, Ian. Islam, Christianity and the Mystic Journey. Edinburgh: Edinburgh University Press, 2011.

Nishida, Kitaro. An Inquiry into the Good. Translated by Masao Abe and Christopher Ives. New Haven, CT: Yale University Press, 1990.

Smith, Mark S. The Early History of God: Yahweh and the Other Deities in Ancient Israel. Dearborn, MI: Eerdmans, 2002.

Smith, Mark S. The Origins of Biblical Monotheism. Oxford: Oxford University Press, 2001.

Stark, Rodney, and William Sims Bainbridge. The Future of Religion: Secularization, Revival, and Cult Formation. Berkeley and Los Angeles: University of California Press, 1985 .

Zevit, Ziony. The Religions of Ancient Israel: A Synthesis of Parallactic Approaches. London: Continuum, 2001. 